Bangladesh J. Pl. Breed. Genet., 29(1): 11-20, 2016

\title{
VARIETAL PERFORMANCE AND CORRELATION OF OKRA POD YIELD AND YIELD COMPONENTS
}

\author{
D. Aminu, O. B. Bello ${ }^{1}$, B. A. Gambo, A. H. Azeez, ${ }^{2}$ J. O. Agbolade ${ }^{3}$ \\ U. A. Abdulhamid and A. Iliyasu \\ Department of Crop Production \\ University of Maiduguri, Nigeria
}

\begin{abstract}
Field irrigation experiments were conducted to assess the varietal performance and correlation of pod yield and yield attributes under irrigation at the Teaching and Research Farm, University of Maiduguri, Nigeria, during 2015 and 2016 dry seasons. The results revealed that the most outstanding for fresh pod yield per plant were okra cultivar Kwadag Y'ar gagure Salkade and, Kwadam in descending order with yield ranging from 580.38-622.67g, while the composite cultivar had the lowest value of pod yield of $428.62 \mathrm{~g}$ over the two years. The highest mean values for number of pods per plant and number of primary branches per plant were observed for Salkade and Y'ar gagure, respectively. Highest fresh pod length and fresh pod diameter were also exhibited for Salkade and Kwadag, respectively. Genotypic coefficient of variation was higher than the phenotypic variation for all the yield contributing characters. Days to 50\% flowering were positive and highly significance difference associated with plant height, number of pods per plant and fresh weight per pod. Path coefficient analysis showed that number of pods per plant exhibited positive and direct effects on pod yield across years. Indirect effect of other yield components through this character also contributed mainly towards pod yield. Therefore, plant height, days to $50 \%$ flowering, number of pods per plant, pod length, pod diameter, number of primary branches per plant and fresh weight per pod could be considered for selection and improvement for high pod yielding varieties in okra.
\end{abstract}

Keywords: Phenotypic; genotypic, correlation coefficient; path analysis; okra pod yield.

\section{INTRODUCTION}

Okra (Abelmoschus esculentus L. Moench) is a member of hibiscus family Malvaceae, and is a popular vegetable in the world; originating from Africa (National Research Council, 2006). It ranks above other vegetable crops including Cabbage Amaranths and Lettuce (Babatunde et al., 2007). Okra is an annual, hardy erect and high yielding plant, which vary in size, pod shape, pigmentation, degree of branching, period of maturity and plant height (Purquerio, et al., 2010). Okra is usually grown in Nigeria during the raining season; it is limited to irrigation in the dry season, especially in the Fadama vegetation (Aladele et al., 2008). Fresh okra fruit, leaves, buds and flowers are consumed as vegetables. The seeds could not only be roasted as a substitute for coffee (Farinde and Owolarafe, 2007), but also as a substitute for aluminium salts in water purification (Camciuc et al, 1998). The pods contain medicinal value. Its mucilaginous preparation can serve as blood volume expander or plasma replacement (Savello et al., 1980). According to Wolford and Banks (2006), okra fresh fruit contain nutrients including water 88\%, protein 1.52 grams, dietary fibre 2 grams, carbohydrates 5.76 grams, vitamin C $13.04 \mathrm{mg}$, vitamin A 460 iu, calcium $0.4 \mathrm{mg}$, folic acid 36.5 micrograms, magnesium $46 \mathrm{mg}$ and potassium $256.6 \mathrm{mg}$ (Zodape $e t$

1 Department of Biological Sciences, Fountain University, Osogbo.

2 Department of Crop, Soil and Pest Management, Federal University of Technology, Akure, Ondo State. Nigeria.

3 Department Plant Science and Biotechnology, Federal University, Oye Ekiti, Nigeria 
al., 2008; Saifullah and Rabbani, 2009). Based on FAO (2004) reports, okra pod which contains vitamin $\mathrm{B}_{6}$, calcium and folic acid could help in good vision, bone formation, growth, proper circulation of blood and digestion. The okra pod protein assists in building muscle tissues and enzymes, which control the hormones of the organs. Its soluble fibre also helps in lowering serum cholesterol, reducing heart disease and cancer, especially colorectal cancer.

Information on genetic variability of crop is essential for identification and breeding of unique accessions vital for curators of gene banks for germplasm conservation (Olaoye, 2009; Bello et al., 2011; 2012ab; 2014ab). Diversity of crops and morpho-agronomical characters are the first step highly recommended to be taken before in-depth molecular and biochemical studies (De Vicente et al., 2005). Knowledge of correlation between pod yield and its related characters could also improve efficiency of selection in okra breeding. Progress and gain from selection in any breeding programme depend upon the magnitude of useful variability present in the population, and the extent to which the desirable characters are heritable. Yield being complex quantitative character and controlled by several genes interact with the environment. Yield is also the product of various factors known as yield components. Efficiency of selection in any breeding programme mainly depends upon the knowledge of association of the characters. The suitable knowledge of such associations between yield and its related characters could appreciably improve efficiency of crop improvement through the use of right selection indices (Adekoya et al., 2014). Correlation coefficient that indicates an association between two characters is useful as a basis for indirect selection for further crop improvement. It is not only assists in the formation of selection indices, but also permits prediction of correlated response. Selection of parents that based on yield alone could be misleading. Correlation analyses are used such that the values of two characters are analyzed on a paired basis, results of which may be either positive or negative. The result of correlation is of great value in the determination of the most effective methods for selection of promising cultivars. If there is positive relationship among major yield characters, component breeding would be very effective, but when these characters are negatively associated, applying simultaneous selection would be difficult in improving the genotypes.

In order to formulate selection indices for genetic improvement of yield, the cause and effect relationship of the trait is very essential, and this can be achieved through path analysis. Path coefficient analysis provides information of effect of each contributing character to yield indirectly and directly (AdeOluwa et al., 2011). The analysis allows breeders to rank genetic components according to their influence It is also essential in indirect selection of elite cultivars from diverse genetic populations. Availability of good information of these genetic components existing in various yield contributing traits and the relative proportion of genetic information in different quantitative attributes are pre-requisites for efficient crop breeding. As okra production play a significant role in the economy of nations as other annual crops, more attention should be accorded to the selection of high yielding cultivars for seed and edible pods. This study was conducted to assess the varietal performance and correlation of pod yield and other related characters of okra cultivars under irrigation with the view to formulating a breeding strategy for improvement, selection and conservation.

\section{MATERIALS AND METHODS}

Field irrigation experiments were conducted at the Teaching and Research Farm, University of Maiduguri $\left(11^{0} 53^{\prime} \mathrm{N}, 16^{\prime} \mathrm{E}\right)$ in the Sudan savannah of Nigeria, during 2015 and 2016 dry seasons. Ten okra cultivars of which four (Kwalpuku, Kwadag, Mola kwadag and Composite) obtained from Borno State Agricultural Programme Maiduguri, Nigeria and six cultivars (Yar'duwi, Salkade, Yar'gagure, Y'ar kwami. Kwadam and Lai-lai) sourced from Gagure Gulani Local Government Area of Yobe State, Nigeria was used as experimental materials.

The field experiment was laid out in Randomized Complete Block Design with three replications. The plot was $216 \mathrm{~m}^{2}$, divided into 33 plots of $2 \mathrm{~m}$ x $2 \mathrm{~m}$ with $1 \mathrm{~m}$ spacing between replications, and $0.5 \mathrm{~m}$ between treatments. Weeding was carried out manually at 3,6, and 9 weeks after sowing (WAS). A 
compound fertilizer, N.P.K. 15:15:15 was applied at the rate of $60 \mathrm{~kg}$ N/ha in two doses, first at three weeks after planting and then at flowering. Two millilitres of Ultracide 40EC insecticide in 15 litres was applied fortnightly to control insect pests. Light watering was applied using a watering can at every morning and afternoon. This was continued for a week for rapid and well establishment of the germinated seedlings.

Six (6) plants were randomly selected from each plot for the assessment of the okra quantitative characters. Data were recorded on days to $50 \%$ flowering, number of primary branches per plant, number of pods per plant, fresh pod length, fresh pod diameter $(\mathrm{cm})$, plant height, fresh weight per pod and fresh pod yield per plant $(\mathrm{g})$.

Statistical analysis of data was computed on all measured traits using the Statistical Analysis System (SAS) software for Windows Version 9.2, (SAS Institute, 2011). Analysis of variance (ANOVA) on yearly basis was first calculated before a combined ANOVA across years. The variability of each agronomic character was estimated by simple measures such as ranges, means, and values of ' $F$ ' (variance ratio) test. The SAS GLM procedure used for the ANOVA was mixed model. Replication was treated as a random effect, while cultivars as fixed effects. The degree of variation was determined using $\%$ coefficient of variation $\mathrm{P}<0.05$. Treatment means were separated by means Duncan Multiple Range Test (DMRT) at 0.05 percent probability suggested by (Gomez and Gomez, 1984). Genotypic and phenotypic variances were estimated as suggested by Johnson et al. (1955).

The correlation coefficients were partitioned into direct and indirect effects using the path coefficient analysis according to Dewey and Lu (1959). Path coefficient analysis was computed according to the procedure employed by Dewey and $\mathrm{Lu}(1959)$.

\section{RESULTS AND DISCUSSION}

The varietal mean performances in the two years on irrigation for okra crop phenology and fruit characters indicated significant differences in the cultivars for all the agronomic characters (Table 1). The most outstanding for fresh pod yield per plant were okra cultivar Kwadag Y'ar gagure Salkade and, Kwadam in descending order with yield ranging from 580.38-622.67g, while the Composite cultivar had the lowest value of pod yield of $428.62 \mathrm{~g}$ over the two years. Subrata et al. (2004) reported that pod yield varied significantly among okra genotypes. The number of pods the flower buds produced is a measure of fruit yield potential, but this potential could not be realised in the two dry seasons because of flower bud abscission. It is however interesting to note that once the flower buds developed into flowers, they have equal chances of developing into pods. Breeding for drought tolerance using number of flower buds could produce a desirable cultivar for the dry season. Plant height at harvest varied from $1.11-1.49 \mathrm{~m}$ with a mean of $1.25 \mathrm{~m}$ (Tables 1 and 2) with Kwadag having the highest. The range observed for days to $50 \%$ flowering was 33.00-50.33 days with overall mean of 46.82 days. This revealed that dissimilar okra cultivars take significantly differed days to flowering; and that cultivars were morphologically different from each other in flower bearing habits. Several researchers have found that days to flowering varied significantly among the okra genotypes (Subrata et al., 2004; Divya and Sreenivasan, 2010; Medagam et al., 2013). The highest mean values for number of pods per plant and number of primarybranches per plant were noted for Salkade, Y'ar gagure, respectively, while highest fresh pod length and fresh pod diameter exhibited for Salkade and Kwadag, respectively. Rashwan (2011) and Singh and Aakansha (2014) earlier observed significant differences among the okra accessions for number of primarybranches per plant, which implied that the collected cultivars were phenotypical different. The mean fresh pod length and fresh pod diameter ranged from $11.49-14.88 \mathrm{~cm}$ and $1.22-1.84 \mathrm{~cm}$ respectively. Highest fresh weight per pod (16.88g) was recorded for Y'ar gagure, while Kwalpuku had the lowest (13.14g). Error of variance of the mean for all the characters was small (Table 2). This might be as a result of optimum number of replications (three) and data used in estimating the components of variance for the characters in the two dry seasons. The wide variability recorded for pod yield among the genotypes shows that there is copious opportunity for selection and improvement. This variability possibly heritable and could be used in the selection processes during breeding programmes. 
Significant positive correlations among yield and yield contributing characters that can increase yield are desirable in crop improvement programmes, because it does not only simplifies selection process, but also gains from selection (Somashekhar et al., 2011; AdeOluwa et al., 2011). The progress of selection not only depends on the knowledge of interrelationships of yield and their relative contributing characters, but also useful in efficient selection of characters. In this study, phenotypic and genotypic correlation coefficients calculated in the examined okra morpho-agronomic characters are presented in Table 2. The phenotypic correlation coefficients of the okra characters revealed the presence of highly significant and positive correlation of number of pods yield per plant with plant height $(\mathrm{r}=0.61)$, days to $50 \%$ flowering $(\mathrm{r}=0.72)$, fresh weight per pod $(\mathrm{r}=0.44)$ and pod length $(0.43)$ (Table 2). This indicated that increasing these attributes could invariably increase pod yield. These results also conformed to previous studies (Ramya and Senhilkumar, 2009; Ramesh et al., 2010; Rashwan, 2011) in which pod yield per plant was positively associated with number ofbranches per plant, number of pods per plant and pod length. The authors further stressed that characters that are genotypically correlated but not phenotypically associated will not be of value in selection, because selection is sometimes due to phenotypical performance of traits. The significant relationship between plant height and pod yield at flowering also revealed that yield improvement via direct selection of plant height during flowering as a single trait could be practicable during crop improvement. Days to $50 \%$ flowering was positive and highly significantly associated with plant height $(\mathrm{r}=0.99)$ and number of pods per plant $(\mathrm{r}=0.45)$ and fresh weight per pod $(\mathrm{r}=0.55)$. The plant height that was positively correlated with days to flowering morphologically indicated that as internodes' formation stops at floral initiation, early maturing okra cultivars usually have short status. Similar findings of fruit yield that was positively and significantly associated with number of pods per plant, plant height, number of branches per plant and weight per pod had been observed by many researchers (Mahaveer et al., 2010; Simon et al., 2013; Mihretu et al., 2014; Kishor et al., 2016). The present study is also agreed with the results reported by Anand et al. (2016) These studies therefore indicated the possibilities of developing early, short and high yielding cultivars by exploiting aforesaid associations.

It is of interest to note that genotypic correlation coefficients (Table 3) were comparable in magnitude with phenotypic coefficients, except number of pods per plant with negative and nonsignificant correlation with fresh pod yield per plant. High genotypic correlation implied that selection of one character directly affected the other character. Conversely, low or non-significant correlation suggested independence of association that would be possible to select for the two characters in question for diverse directions. There were positive significant phenotypic and genotypic correlations of fresh weight per pod with days to $50 \%$ flowering, pod length and pod diameter, similar to the findings of Rashwan (2011). This also revealed that genetic factors were responsible for these associations. The significant positive association between plant height and number of pods per plant was not surprising, because pods in okra are usually borne in the leaf axil at the nodes; and number of pods per plant was found to be strongly correlated positively with number of nodes on the main stem (Bhalekar et al. 2005). Delay in fruiting could be as a result of prolonged vegetative growth induced by certain factors of the environment such as photoperiod. Even though, both phenotypic and genotypic correlations were comparable in magnitude, genotypic correlations in general were higher than phenotypic correlations for all pairs of characters, indicating that these characters were genetically controlled, and that their expression are lessened under the influence of environment. Several workers (Akinyele and Osekita, 2006, Mehta et al., 2006, Ahiakpa et al., 2011, Bello et al., 2012) reported that phenotypic correlation is an aggregate of genotypic and environmental correlations. Although, it has been noted that genotypic correlations were always greater than phenotypic correlations coefficients in many crops. The association of pod yield and days to $50 \%$ flowering was negative and significant at both genotypic and phenotypic levels in this study. This connoted that exceedingly early maturity might enhance decline in pod yield of okra (Rashwan, 2011, Adekoya et al., 2014, Ahamed et al., 2015, Tesfa et al., 2016). 
Table 1. Combined mean performance of ten okra genotypes for fresh pod yield per plant and other related characters under irrigation between 2015 and 2016 dry seasons in Maiduguri (Nigeria)

\begin{tabular}{|c|c|c|c|c|c|c|c|c|}
\hline Genotypes & $\begin{array}{l}\text { Days to } \\
50 \% \\
\text { flowering }\end{array}$ & $\begin{array}{l}\text { Plant height at } \\
\text { harvest }(\mathrm{m})\end{array}$ & $\begin{array}{l}\text { Number of primary } \\
\text { branches per plant } \\
\text { (no.) }\end{array}$ & $\begin{array}{c}\text { Number of pods } \\
\text { per plant (no) }\end{array}$ & $\begin{array}{l}\text { Fresh pod } \\
\text { length } \\
(\mathrm{cm})\end{array}$ & $\begin{array}{l}\text { Fresh pod } \\
\text { diameter } \\
(\mathrm{cm})\end{array}$ & $\begin{array}{l}\text { Fresh } \\
\text { weight per } \\
\text { pod }(\mathrm{g})\end{array}$ & $\begin{array}{l}\text { Fresh pod } \\
\text { yield per } \\
\text { plant }(\mathrm{g}) .\end{array}$ \\
\hline Y'ar duwi & 43.11 & 1.14 & 2.84 & 25.34 & 12.34 & 1.56 & 15.96 & 479.38 \\
\hline Salkade & 50.33 & 1.44 & 4.23 & 33.75 & 14.88 & 1.22 & 16.23 & 598.65 \\
\hline Y'ar gagure & 50.75 & 1.39 & 3.51 & 34.45 & 14.73 & 1.83 & 16.56 & 616.97 \\
\hline Composite & 44.23 & 1.11 & 1.89 & 22.54 & 12.52 & 1.48 & 14.73 & 428.62 \\
\hline Kwalpuku & 43.00 & 1.18 & 3.18 & 23.92 & 11.49 & 1.51 & 13.14 & 488.38 \\
\hline Kwadag & 49.31 & 1.49 & 3.75 & 34.35 & 14.37 & 1.84 & 16.83 & 622.67 \\
\hline Mola kwadag & 49.11 & 1.21 & 2.66 & 24.88 & 12.84 & 1.48 & 14.64 & 457.92 \\
\hline$Y^{\prime}$ ar kwami & 45.34 & 1.18 & 3.33 & 25.18 & 13.37 & 1.52 & 14.34 & 431.63 \\
\hline Kwadam & 45.11 & 1.22 & 1.67 & 28.23 & 13.64 & 1.44 & 15.11 & 580.38 \\
\hline Lai-lai & 47.93 & 1.16 & 2.12 & 28.64 & 11.59 & 1.52 & 14.98 & 532.85 \\
\hline Mean & 46.82 & 1.25 & 2.92 & 28.03 & 13.08 & 1.54 & 15.25 & 523.75 \\
\hline Range & 7.33 & 0.38 & 2.56 & 11.91 & 3.39 & 0.62 & 3.68 & 194.05 \\
\hline $\mathrm{SE} \pm$ & 11.849 & 6.111 & 2.759 & 6.654 & 6.149 & 11.234 & 10.171 & 11.73 \\
\hline $\operatorname{LSD} \alpha 0.05$ & $2.23 *$ & $1.11^{*}$ & $1.45^{*}$ & $4.62 * *$ & $2.14^{*}$ & $1.01 *$ & $1.43^{*}$ & 3.57 \\
\hline CV\% & 4.36 & 7.82 & 6.39 & 4.92 & 10.52 & 7.45 & 7.18 & 6.83 \\
\hline
\end{tabular}

Fresh pod yield per plant of pods per weight per pod

Table 2. Ranges, means, and values of ' $F$ ' from estimates for fresh pod yield per plant and other related characters of okra cultivars under irrigation between 2015 and 2016 dry seasons in Maiduguri (Nigeria)

\begin{tabular}{|c|c|c|c|c|c|c|}
\hline Characters & Range of variation & Means & S.E & Standard deviation & Error variance & $\mathrm{F}$ value \\
\hline Days to $50 \%$ flowering & $33.00-50.33$ & 46.82 & 0.91 & 3.45 & 0.54 & 45.28 \\
\hline Plant height at harvest (m) & $1.11-1.49$ & 1.25 & 0.84 & 0.33 & 7.25 & 26.72 \\
\hline Number of primary branches per plant & $1.67-4.23$ & 2.92 & 1.25 & 0.34 & 3.52 & 35.98 \\
\hline Number of pods per plant & $22.54-34.45$ & 28.03 & 1.12 & 1.48 & 2.35 & 10.63 \\
\hline Fresh pod length $(\mathrm{cm})$ & $11.49-14.88$ & 13.08 & 1.38 & 1.32 & 7.75 & 40.73 \\
\hline Fresh pod diameter $(\mathrm{cm})$ & $1.22-1.84$ & 1.54 & 1.52 & 0.87 & 0.53 & 22.53 \\
\hline Fresh weight per pod (g) & $13.14-16.88$ & 15.25 & 1.58 & 0.12 & 3.78 & 33.54 \\
\hline Fresh pod yield per plant $(\mathrm{g})$. & $428.62-622.67$ & 523.75 & 0.47 & 0.83 & 1.52 & 67.93 \\
\hline
\end{tabular}

PHT: plant height (cm), DF: Days to 50\% flowering, NBP: Number of primarybranches per plant, NPP: Number of pods per plant, PL: Pod length (cm), PD: Pod diameter $(\mathrm{cm})$, FPW: Fresh weight per pod $(\mathrm{g})$ and FPY: Fresh pod yield per plant $(\mathrm{g})$ 
Table 3. Genotypic and phenotypic correlations for okra pod yield and yield attributes combined across years under irrigation in Maiduguri, Nigeria

\begin{tabular}{lccccccccc}
\hline S/N & & PHT & DF & NBP & NPP & PL & PD & FPW & FPY \\
\hline PHT & rg & 1.00 & & & & & & & \\
& $\mathrm{rp}$ & 1.00 & & & & & & & \\
DF & $\mathrm{rg}$ & $-0.55^{* *}$ & 1.00 & & & & & \\
& $\mathrm{rp}$ & $-0.53^{* *}$ & 1.00 & & & & & \\
$\mathrm{NBP}$ & $\mathrm{rg}$ & 0.21 & 0.26 & 1.00 & & & & \\
& $\mathrm{rp}$ & 0.22 & 0.27 & 1.00 & & & & \\
$\mathrm{NPP}$ & $\mathrm{rg}$ & $0.52^{* *}$ & $0.47^{* *}$ & 0.19 & 1.00 & & & & \\
& $\mathrm{rp}$ & $0.48^{* *}$ & $0.46^{* *}$ & 0.20 & 1.00 & & & & \\
$\mathrm{PL}$ & $\mathrm{rg}$ & $0.60^{*}$ & 0.14 & $-0.50^{* *}$ & 0.18 & 1.00 & & & \\
& $\mathrm{rp}$ & $0.59^{*}$ & 0.11 & $-0.47^{* *}$ & 0.19 & 1.00 & & & \\
$\mathrm{PD}$ & $\mathrm{rg}$ & 0.18 & 0.11 & -0.13 & -0.30 & -0.22 & 1.00 & & \\
& $\mathrm{rp}$ & 0.17 & 0.13 & -0.10 & -0.27 & -0.19 & 1.00 & & \\
$\mathrm{FW}$ & $\mathrm{rg}$ & 0.29 & $0.52^{* *}$ & 0.18 & 0.10 & $0.53^{* *}$ & $0.85^{* *}$ & 1.00 & \\
$\mathrm{P}$ & $\mathrm{rp}$ & 0.25 & $0.48^{* *}$ & 0.10 & 0.07 & $0.51^{* *}$ & $0.78^{* *}$ & 1.00 & \\
$\mathrm{FPY}$ & $\mathrm{rg}$ & $0.61^{* *}$ & $-0.51^{* *}$ & $0.32^{*}$ & $0.79^{* *}$ & $0.72^{* *}$ & 0.25 & $0.75^{* *}$ & 1.00 \\
& $\mathrm{rp}$ & $0.50^{* *}$ & $-0.43^{* *}$ & $0.29^{*}$ & $0.65^{* *}$ & $0.63^{* *}$ & 0.20 & $0.61^{* *}$ & 1.00 \\
\hline
\end{tabular}

***, significant at $\mathrm{P}<0.05$ and $\mathrm{P}<0.01$ respectively.

PHT: plant height (cm), DF: Days to 50\% flowering, NBP: Number of primary branches per plant, NPP: Number of pods per plant, PL: Pod length $(\mathrm{cm})$, PD: Pod diameter $(\mathrm{cm})$, FPW: Fresh weight per pod (g) and FPY: Fresh pod yield per plant $(\mathrm{g})$.

Since the pod yield did not phenotypically and genotypically correlated with days to $50 \%$ flowering, deviations from anthesis to physiological maturity could influence pod yield compared with plant emergence to anthesis period. Correlation between pod yield and pod diameter was low at phenotypic and genotypic levels in the two years, indicating that there's ample opportunity of receiving plum pods with least leeway in improving pod yield. The significant phenotypic and genotypic relationship between fresh pod yield per plant and number ofbranches per plant and plant height could be related to appropriate light interception provided by greater height. This could also provide higher photosynthetic capacity acquired by more leaves that were abided on the branches (Stevels et al. 2012). It is from the leaves that the plants manufacture their food through photosynthesis. The higher number of leaves, the higher the yield in crops. This is based on higher photosynthetic capacity and photosynthetically active radiation (PAR) via enhanced leaf area index, higher intercepted and fraction of intercepted radiation (FI) as well as its utilization efficiency. Also in okra, more branches produced increased fruit bearing nodes.

Pod yield of okra is governed by several agronomic traits with either indirectly or directly contribution to the yield. Path coefficient analyses used to obtain further information on the interrelationships among morpho-agronomic characters and their effects on okra fresh pod yield per plant are presented in Table 4. Number of pods per plant had greatest direct effect on pod yield $(p=6.63)$, followed by fresh weight per pod $(\mathrm{p}=6.13)$ which had positive genotypic association with pod yield. Previous literatures of path coefficient analysis revealed that number of pods per plant and fruit weight had positive and high direct effects on fruit yield, indicating their importance as reliable selection criteria for improvement of yield in okra (Subrata et al., 2004; Adeniji and Aremu, 2007). It is of the opinion that by increasing ear weight due to more absorption of photo assimilates, the most portion of assimilates remobilize to grains, and invariably increase grain weight. However, as direct and indirect influences of number of pods per plant were prominent, these had a positive impact on pod length and pod diameter which could be a cause for high correlation coefficient that existed between pod yield and number of pods per plant $(\mathrm{rg}=0.77)$. Direct response of this character could be attributed to indirect positive influence of plant height, days to 50\% flowering, pod length and fresh weight per pod. Some researchers 
reported that plant height had positive direct effect on okra pod yield per plant (Akinyele and Osekita, 2006; Saifullah and Rabbani, 2010; Solankey and Singh, 2010). This therefore suggests the vital and successful achievement in selecting for these characters when high yield is the objective. Pod length had the highest negative direct influence on pod yield despite its positive genotypic interrelation with pod yield. This showed the flaw of selecting on the basis of inter-character correlation only. Therefore, selection of this character may not produce the desired results. Though, the direct effect of plant height on fruit yield was negative $(\mathrm{p}=-3.56)$, its correlation coefficient was also negative $(\mathrm{rg}=-0.58)$, but has high positive indirect influence on pod length and number of pods per plant.

Table 4. Path coefficient of okra fresh pod yield and yield attributes combined across years under irrigation in Maiduguri, Nigeria

\begin{tabular}{l|c|c|c|c|c|c|c|c|c}
\hline Character & Genotypic & Direct & \multicolumn{9}{|c}{ Indirect effects } \\
\cline { 6 - 11 } & correlation & effect & PHT & DF & NBP & NPP & PL & PD & FWP \\
\hline PHT & $0.58^{* *}$ & -3.56 & & 1.67 & 0.47 & -0.56 & 1.31 & -0.76 & 0.17 \\
DF & $-0.48^{* *}$ & -0.87 & 0.41 & & 0.18 & 0.12 & 1.29 & 0.64 & 0.41 \\
NBP & $0.27^{*}$ & -1.67 & -0.55 & 0.59 & & 0.13 & 0.45 & 0.83 & 0.73 \\
NPP & $0.77^{* *}$ & 6.63 & 0.80 & 2.83 & -2.05 & & 1.23 & -1.71 & 0.34 \\
PL & $0.74^{* *}$ & -3.57 & 0.92 & 1.45 & -1.72 & 0.49 & & 3.11 & 0.59 \\
PD & 0.21 & 3.76 & -0.30 & -5.33 & 2.11 & -0.73 & 1.33 & & -0.42 \\
FWP & $0.62^{* *}$ & 6.13 & -0.63 & -7.76 & -0.79 & 0.81 & -4.81 & 1.22 & \\
\hline
\end{tabular}

$*$,**, significant at $\mathrm{P}<0.05$ and $\mathrm{P}<0.01$ respectively.

Residual effect $(\mathrm{h}=0.30)$. PHT: plant height $(\mathrm{cm})$, DF: Days to $50 \%$ flowering, NBP: Number of primary branches per plant, NPP: Number of pods per plant, PL: Pod length $(\mathrm{cm})$, PD: Pod diameter $(\mathrm{cm})$ and FWP: Fresh weigh per pod $(\mathrm{g})$.

Regardless of the importance of pod yield contributing trait used in path coefficient analysis computation, the residual effect $(h=0.10)$ is relatively low, denoting that the characters considered in this analysis is sufficiently explained the variability in okra yield as supported by many researchers (Mahaveer et al., 2010; Akanbi et al., 2015; Mishra et al., 2015; Demelie et al., 2016). It is projected that 78.93\% difference in pod yield at a genotypic level is determined. This further portrayed occurrence of some factors that contributed to okra pod yield that were not considered in this study. This could also be that correlation coefficients were ordinary estimates and are used to always rounding-off errors. Days to 50\% flowering, pod length, number of pods per plant and weight per pod appeared to be the favourable characters that could be used in selecting for high pod yield in okra, because of their highly significant genotypic and phenotypic correlations with fresh pod yield per plant in this study. It was also observed by Alam et al. (2008) and Jagan et al. (2013) that significant increased in each of these parameters tested could lead to an increase in the total okra pod yield. These evaluated characters also had the highest direct and indirect effects through most of the other characters. It is apparent that these prominent agronomic parameters could be considered as important selection criteria in improving okra varieties for high pod yield.

\section{ACKNOWLEDGMENTS}

The authors appreciated the Farm Manager and the team of Teaching and Research Farm, University of Maiduguri, Maiduguri, Nigeria for providing all necessary facilities to carry out the research.

\section{REFERENCES}

Adekoya, M. A., O. J. Ariyo, O. B. Kehinde and A. E. Adegbite. 2014. Correlation and path analyses of seed yield in okra (Abelmoschus esculentus (L.) Moench) grown under different cropping seasons. Pertan. J. Trop. Agric. Sci. 37(1): 39-49. 
Adeniji, O.T., O. B. Kehinde, M. O. Ajala and M. A. Adebisi. 2007. Genetic studies on seed yield of West African okra ( Abelmoschus caillei) (A chev.) Stevels). J. Trop. Agric. 45(1-2): 36-41.

Ade Oluwa, O. O. and O. B. Kehinde. 2011. Genetic variability studies in West African Okra (Abelmoschus caillei). Agric. Biol. J. North Ame. 2(10): 1326-1335.

Ahamed, K. U, B. Akter, N. Ara, M. F. Hossain and M. Moniruzzaman. 2015. Heritability, correlation and path coefficient analysis in fifty seven okra genotypes. Inter. J. Appl. Sci. Biotechnol. 3(1): 127-133.

Ahiakpa, P. D., E. B. Kaledzi, S. Adi, H. K. Peprah, A. M. A. Dapaah and A. Rashwan. 2011. Study of genotypic and phenotypic correlation for some agro-economic traits in okra (Abelmoschus esculentus (L.) Moench). Asian J. Crop Sci. 3: 85-91.

Akanbi, W.B., A. O. Togun, J. A. Adediran and E. A. O. Ilupeju. 2010. Growth, dry matter and fruit yield components of okra under organic and inorganic sources of nutrients. American-Eurasian J. Sustain. Agric.. 4(1): 1-13.

Akinyele, B. O. and O. S. Osekita. 2006. Correlation and path coefficient analyses of seed yield attributes in okra (Abelmoschus esculentus (L.) Moench). Afr. J. Biotechnol. 5(14): 1330-1336.

Aladele, S. E., O. J. Ariyo and R. de Lapena. 2008. Genetic relationship among West African okra (Abelmoschus caillei) and Asian genotypes (Abelmoschus esculentus) using RAPD. Afr. J. Biotechnol. 7: $1426-1431$.

Alam, A. K. M. A., M. M. and Hossain. 2008. Variability of different growth contributing parameters of some okra (Abelmoschus esculentus L.) accessions and their interrelation effects on yield. J. Agric. Rural Dev.. 6(1-2): 25-35.

Anand, C., S. Kartikeya, A. Vishal and K. Santosh. 2016. Elucidation of variability, interrelationships and path-coefficient in maize (Zea mays L.). Nat. Env. Pollut. Technol. 15(2): 653-656.

Babatunde, R. O., O.A. Omotesho, and S. O. Sholoton. 2007. Socio-economic characteristics and food security status of farming household in Kwara State, North Central Nigeria. Pak. J. Nutr. 6(1): $16-22$.

Bello, O. B., M. S. Afolabi, S. A. Ige, S. Y. Abdulmaliq, M. A. Azeez, J. Mahmood. 2011. Yield response of diallelic crossed maize (Zea mays L.) genotypes to varying nitrogen regimes in Nigeria. J. Bio-Sci. 19: 43-52.

Bello, O. B., S. Y. Abdulmaliq, S. A. Ige, J. Mahmood, F. Oluleye, M. A. Azeez, M. S. Afolabi. 2012a. Evaluation of early and late/intermediate maize varieties for grain yield potential and adaptation to a southern guinea savanna agro-ecology of Nigeria. Intern. J. Plant Res. 2(2): 14-21.

Bello, O. B., M. S. Afolabi, S. A. Ige, S. Y. Abdulmaliq, M. A. Azeez and J. Mahmood. 2012b. Nitrogen use efficiency and grain yield in a diallelic cross of maize populations. Inter. J. Plant Res. 2(3): 94-102.

Bello, O. B., O. J. Olawuyi, Ige SA, J. Mahsmood, M. S. Afolabi, M. A. Azeez and S. Y. Abdulmaliq. 2014a. Agro nutritional variations of quality protein maize (Zea mays L.) in Nigeria. J.Agric. Sci.. 59(2): 101116.

Bello, O. B., O. J. Olawuyi, S. Y. Abdulmaliq, S. A. Ige, J. Mahmood, M. A. Azeez and M. S. Afolabi. 2014b. Yield performance and adaptation of early and intermediate drought-tolerant maize genotypes in Guinea savanna of Nigeria. Sarhad J. Agric. 30(1): 5366.

Bello, O. B., and O. J. Olawuyi. 2015. Gene action, heterosis, correlation and regression estimates in developing hybrid cultivars in maize. Trop. Agric. 92(2): 102117.

Bhalekar, S. G., C. A. Nimbalkar. and U. T. Desai. 2005. Correlation and path analysis studies in okra. J. Maharashtra Agric. Univ. 30(1): 109-112.

Camciuc, M., M. Deplagne, G. Vilarem and A. Gaset. .1998. Okra-Abelmoschus esculentus L. (Moench.) a crop with economic potential for set aside acreage in France. Ind. Crops Prod. 7: 257-264.

Demelie M, Mohamed W and Gebre E (2016). Variability, heritability and genetic advance in Ethiopian okra [Abelmoschus esculentus (L.) Monech] collections for tender fruit yield and other agromorphological traits. Journal of Applied Life Sciences International 4(1):1-12. 
De Vicente, M. C., F. A. Guzman, J. Engels and V. R. Rao. 2005. Genetic characterization and its use in decision making for the conservation of crop Germplasm. The Role of Biotechnology, March 5 7, 2005, Villa Gualino, Turin, Italy.

Dewey, D. R. and K. H. Lu. 1959. A correlation and path coefficient analysis of components of creast wheat grass seed production. Agron. J .Hort. 57(4): 342-346.

Divya, B. and E. Sreenivasan. 2010. Correlation and path analysis studies in okra [Abelmoschus esculentus (L.) Moench]. Madr. Agric. J. 97(10-12): 326-328.

FAO. 2004. An ecological guide: Training resource text on crop development, major economic practices, disease and insect ecology, insect pests, natural enemies and diseases of okra. The National Academies Press, http://www.vegetableipmasia.org/docs/Ecological \%20Guide/OKRA\%20 ECO\%20GUIDE.pdf.

Farinde, A. O. and L. B. Owalarefe. 2007. Nigeria fertilizer sector, present situation and future prospects IFDC. Technical Bulletin 12(1): 18-25.

Gomez, K. A. and A. A. Gomez. 1984. Statistical Procedure for Agricultural Research (2 $2^{\text {nd }}$ edn.). International Rice Research Institute, A Willey Institute of Science, pp. 28-192.

Jagan, K., R. K. Ravinder, M. Sujatha, R. Madhusudhan and V. Sravanthi. 2013. Correlation and path coefficient analysis for certain metric traits in okra (Abelmoschus esculentus (L.) Moench) using line x tester analysis. Inter. J. Innov. Res. Dev. 2(8): 287-293.

Johnson, H. W., H. F. Robinson and R. E. Comstock. 1955. Estimation of genetic and environmental variability in soybeans. Agron. J. 47: 314-318.

Kishor, D. S., K. Arya, K. J. Yogeesh, K. Y. Vinod and K. Hee-Jong. 2016. Genotypic variation among okra ( Abelmoschus esculentus (L.) Moench) germplasms in South Ind. Plant Breed. Biotechnol. 4(2): 234-241.

Mahaveer, K., E. Gangappa and R. G. Satish. 2010. Correlation and path coefficient analysis of yield and yield components in okra (Abelmoschus esculentus L. Moench.). Env. Ecol. 28(4A): 2625-2628.

Medagam, T. R., H. B., G. Mutyala, C. R. Konda, B. Hameedunnisa, S. K. R. Reddivenkatagari, and D. B. Jampala. 2013. Correlation and path coefficient analysis of quantitative characters in okra (Abelmoschus esculentus (L.) Moench). Songklanakarin J. Sci. Technol. 35(3): 243-250.

Mehta, D. R., Dhaduk, L.K. and K. D. Patel. 2006. Genetic variability, correlation and path analysis studies in okra \{Abelmoschus esculentus (L.) Moench\}. Agric. Sci. Digest. 26(1): 15-18.

Mihretu, Y., G. Weyessa and D. Adugna. 2014. Variability and association of quantitative characters among okra (Abelmoschus esculentus (L.) Moench) collection in South Western Ethiopia. J. Bio. Sci. 14: 336-342.

Mishra, A., H. N. Mishra, N. Senapati and P. Tripathy. 2015. Genetic variability and correlation studies in Okra (Abelmoschus esculentus (L.) Monech), Electron. J. Plant Breed. 6(3):866-869.

National Research Council. 2006. Lost Crops of Africa: Volume II: Vegetables. Washington, DC, pp. 286-301.

Olaoye, G., O. B. Bello, L. S. Olayiwola and A. Y. Abubakar. 2009. Analyses of moisture deficit grain yield loss in drought tolerant maize (Zea mays L.) germplasm accessions and its relationship with field performance. Afr. J. Biotechn. 8(14):3229 3238.

Purquerio, L. F. V., Lago, A. A., Passos, F. A. 2010. Germination and hard seedness of seeds in okra elite lines. Hort. Brasil Brasília. 28(2): 23-32.

Ramesh, K., K. Sangita and Y.R. Shukla. 2010. Variability, correlation and path analysis studies in Lettuce. Inter. J. Veget. Sci. 16: 299-315.

Ramya, K. and N. Senthilkumar. 2009. Genetic divergence, correlation and path analysis in okra (Abelmoschus esculentus). Madras Agric. J. 96: 296-299.

Rashwan, A. M. A. 2011. Study of genotypic and phenotypic correlation for some agro-economic traits in okra (Abelmoschus esculentus). Asian Crop Sci. 3: 85-91.

Saifullah M and M. G. Rabbani. 2009. Evaluation and characterization of Okra (Abelmoschus esculentus L. Moench.) genotypes. SAARC J. Agric.. 7(1): 92-99.

SAS. 2011. Statistical analysis system (SAS) software for windows version 9.2. Vol.1. SAS Institute. Cary, N.C. USA. 
Savello, P. A., F. W. Mortin and J. M. Hill. 1980. Nutritional composition of okra seed meal. Agric. Food Chem. 28: 1163-1166.

Simon, S. Y., I. B. Gashua and I. Musa. 2013.Genetic variability and trait correlation studies in okra [Abelmoschus esculentus (L.) Moench]. Agric. Bio. J. North Ame. 10: 532-538.

Singh, R. K. and B. D. Chaudhury. 1985. Biometrical method in quantitative genetics analysis (Rev. ed.). Kalyain Publishers, New Delhi, India, pp. 78-85.

Singh, B. and G. Aakansha. 2014. Correlation and path coefficient analysis in okra (Abelmoschus esculentus). Indian J. Agric. Sci. 84(10): 1262-1266.

Solankey, S. S. and A. K. Singh. 2010. Correlation studies in okra (Abelmoschus esculentus L. Moench). Asian J. Hort. 5(1): 70-75.

Somashekhar, G., H. D. Mohankumar and P. M. Salimath. 2011. Genetic analysis of association studies in segregating population of okra. Karnataka J. Agric. Sci. 24(4): (432-435).

Stevels, C. O. A., O. J. Ariyo and M. A. Ayo-Vaughan. 2012. Genotypic performance, character correlations and path analysis of pod yield in Abelmoschus caillei (A. Chev.). Italian J. Agron. 7(E44): 337-345.

Subrata, S., P. Hazra and A. Chattopadhyay. 2004. Genetic variability, correlation and path analysis in okra (Abelmoschus esculentus L. Moench). Hort. J. 17(1): 59-66.

Tesfa, B. and A. Yosef. 2016. Characterization of okra (Abelmoschus esculentus (L.) Moench) germplasms collected from Western Ethiopia. Inter. J. Res. Agric. For. 3(2): 11-17.

Wolford, R. and D. Banks. 2006. Okra (http://www.urbanext.uivc/veggies/okra 1.htm)

Zodape, S.T., V.J. Kawarkhe, J. S. Patolia, and A. D. Warade. 2008. Effect of liquid seaweed fertilizer on yield and quality of okra (Abelmoschus esculentus L.). J. Sci. Ind. Res. 67: 1115-1117. 